\title{
Sistem Embedded Cerdas Menggunakan Logika Fuzzy Untuk Efisiensi Konsumsi Energi Listrik
}

\author{
Ramzi Adriman, Muhammad Asfianda, Afdhal A., Yuwaldi Away \\ Jurusan Teknik Elektro dan Komputer Universitas Syiah Kuala \\ Jalan Tgk. Syech Abdurrauf No.7 Kopelma Darussalam Kecamatan Syiah Kuala, Kota Banda \\ Aceh, Propinsi Aceh, Indonesia \\ e-mail: ramzi.adriman@unsyiah.ac.id, asfianda@gmail.com, afdhal@unsyiah.ac.id, \\ yuwaldi@unsyiah.ac.id
}

\begin{abstract}
The industrial growth, the use of electronic appliances for offices and households are contributing to increasing the energy consumption annually. It potentially affects the environmental damage and global warming. The Role of government and environmental organizations through energy awareness campaigns in the community is not sufficient. This research is to develop the prototype of the smart embedded system that controls the use of electronic appliances using the Fuzzy Logic method, so the system can manage the electricity consumption automatically. The system is designed using an Arduino Nano microcontroller is integrated with temperature sensors, motion sensors, and Real Time Clock (RTC) modules. In the performance testing phase, the system connected to various electronic equipment such as air conditioner, lamp, an electric circuit breaker (outlet). Based on the test results the smart embedded system able to control the use of the electronic device and save electrical energy up to $28.71 \%$.
\end{abstract}

Keywords: Smart embedded system; Fuzzy; Arduiono nano; Energy eficiency

\begin{abstract}
Abstrak
Bertambahnya pertumbuhan industri, penggunaan alat elektronik untuk kebutuhan kantor dan rumah tangga menjadi kontribusi peningkatan konsumsi energi pada setiap tahunnya sehingga berpotensi menimbulkan pemborosan pemakaian energi yang berdampak pada lingkungan dan pemanasan global. Pengendalian konsumsi energi listrik oleh pemerintah dan organisasi peduli ingkungan melalui kampanye kesadaran hemat energi pada masyarakat dinilai belum cukup efektif dan efisien. Penelitian ini membuat purwarupa sistem embedded cerdas yang dapat mengendalikan penggunaan peralatan elektronik menggunakan metode Logika Fuzzy sehingga pengendalian konsumsi energi listrik dapat dilakukan secara otomatis. Sistem ini dirancang dengan menggunakan mikrokontroller Arduino Nano yang diintegrasikan dengan sensor suhu, sensor gerak dan modul Real Time Clock (RTC). Pada tahap pengujian kinerja, sistem ini dihubungkan dengan berbagai peralatan elektronik seperti pendingin ruangan, lampu, dan tempat penghubung arus listrik (stopkontak). Berdasarkan hasil pengujian dapat disimpulkan bahwa penerapan sistem embedded cerdas mampu mengendalikan konsumsi energi dan menghemat energi listrik hingga $28,71 \%$.
\end{abstract}

Kata kunci: Sistem embedded cerdas; Fuzzy; Arduino nano; Efisiensi energi

\section{Pendahuluan}

Berdasarkan Energy Information Admnistration Amerika Serikat pada International Energy Outlook 2017 pemenuhan konsumsi energi listrik terus meningkat. Bertambahnya pertumbuhan industri, penggunaan alat elektronik untuk kebutuhan kantor dan rumah tangga menjadi kontribusi peningkatan tren kebutuhan energi listrik tersebut [1]. Peningkatan kebutuhan energi ini diperkirakan akan tetap terjadi dimasa yang akan datang yang mengakibatkan pemanasan global dan dampak lingkungan lainnya [2]. Masih sedikit pengguna listrik yang menyadari bahwa penggunaan energi selama ini kurang efektif dan efisien sehingga terjadi pemborosan dan berpotensi memicu krisis lingkungan dan energi dunia. Dalam rangka penghematan pemakaian 
energi listrik, Pemerintah Republik Indonesia menerbitkan Peraturan Menteri Energi dan Sumber Daya Mineral Republik Indonesia Nomor 13 Tahun 2012 tentang Penghematan Pemakaian Energi Listrik. Dalam peraturan tersebut disebutkan permasalan krisis energi ini dapat diatasi dengan mematikan peralatan elektronik yang tidak digunakan seperti pada saat ruang kosong atau ketika tidak diperlukan sehingga dapat menghemat energi. Pada kenyataannya pengguna belum dapat melaksanakannya sesuai dengan yang telah diatur dalam regulasi tersebut. Solusi pengendalian konsumsi energi dengan mendorong kesadaran masyarakat dinilai masih belum efektif dan efisien.

Penelitian yang dilakukan oleh peneliti sebelumnya [3 -6], menggunakan logika metode fuzzy untuk efisiensi konsumsi energi listrik fokus pada pengaturan satu jenis peralatan elektronik. Konsep Building Management Systems (BMS) [3]. BMS digunakan untuk memonitor dan mengendalikan Heating, Ventilation, and Air Conditioning (HVAC). Adapun pengembangan Type2 Fuzzy Logic Controller (Tipe-2 FLC) sebagai pengendali kecepatan yang bertindak sebagai Driver Model Controller (DMC) pada Autonomous Electric Vehicles (AEV) [4]. DMC diimplementasikan menggunakan perangkat keras pengendali secara real time menggunakan Integral Absolute Error (IAE). Kinerja yang dihasilkan oleh sistem tersebut kemudian dibandingkan dengan Type-1 Fuzzy Logic and Proportional Integral Derivative DMCs. Peneliti lain mengembangkan sebuah sistem retrofit berbasis logika fuzzy untuk melakukan efisiensi energi secara cerdas pada kompor listrik [5]. Sistem yang dikembangkan tersebut dapat mengendalikan plat pemanas pada kompor listrik sehingga memungkinkan aman dioperasikan secara semiotomatis. Penelitian menggunakan logika fuzzy yang diterapkan pada sistem pendingin udara dengan mencari aturan operasi melalui fungsi atribusi fuzzy [6]. Suhu dan kelembaban dijadikan sebagai input untuk mencapai kestabilan kecepatan kompresor. Sistem pendingin udara bekerja dengan mengaktifkan (on) dan menonaktifkan (off) mesin pendingin di kisaran suhu tertentu. Kompresor dikendalikan oleh logika fuzzy dengan cara memperkenalkan fungsi keanggotaan fuzzy untuk mencapai kontrol yang lebih tepat dari kompresor. Hasil yang didapatkan pada penelitian tersebut dapat ditingkatkannya efisiensi energi sehingga siklus hidup kompresor dapat diperpanjang dengan baik.

Dalam penelitian ini, penulis membuat purwarupa sistem tertanam (embedded) cerdas untuk pengendalian konsumsi energi sehingga dijadikan sebagai salah satu solusi untuk mengatasi permasalahan krisis energi. Hal ini bertujuan untuk mengelola penggunaan energi listrik secara cerdas pada seluruh alat elektronik yang dianggap perlu sehingga dapat meningkatkan efisiensi konsumsi listrik. Sistem yang ditawarkan oleh penelitian ini adalah pengendalian konsumsi energi listrik dengan penerapan metode logika fuzzy. Sistem embedded cerdas merupakan sistem embedded yang dirancang dengan menggunakan mikrokontroller Arduino Nano yang diintegrasikan dengan sejumlah sensor suhu, sensor gerak dan modul Real Time Clock (RTC). Sistem ini kemudian dihubungkan dengan berbagai peralatan elektronik rumah tangga seperti pendingin ruangan, lampu, dan stopkontak, sehingga penggunaannya dapat dikendalikan dan bila ada peralatan elektronik dalam keadaan tidak digunakan dalam jangka waktu tertentu akan dimatikan secara otomatis. Selanjutnya, artikel ini diorganisasikan sebagai berikut: pada bagian 2 dibahas metode dan perancangan sistem. Pada bagian 3 akan dibahas tentang hasil dan analisis, sedangkan pada bagian 4 akan dirangkum sejumlah kesimpulan dari penelitian ini.

\section{Metode Penelitian}

Logika fuzzy adalah sebuah logika yang memiliki nilai keabuan atau kekaburan dengan nilai antara 0 dan 1 yang dapat diartikan "salah" dan "benar". Logika fuzzy merupakan sebuah nilai dapat bernilai "salah" dan "benar" secara bersamaan. Besar kebenaran dan kesalahannya bergantung pada bobot keanggotaan yang dimilikinya. Pengelompokannya dapat dilakukan berdasarkan variabel bahasa (linguistic variable) dalam fungsi keangotaan yang disebut himpunan fuzzy (fuzzy set), contohnya himpunan variabel bahasa dari suhu adalah panas, hangat, normal, sejuk dan dingin [7].

Oleh karena itu, logika fuzzy sangat memungkinkan digunakan untuk pengendalian dari suatu obyek dengan tujuan tertentu. Pada penelitian ini, logika fuzzy digunakan sebagai pengendali konsumsi energi, dimana energi sebagai objek dapat dikendalikan sehingga dapat digunakan secara efektif dan efisien.

Dalam pelaksanaan penelitian sistem ini menggunakan logika fuzzy, metode yang digunakan adalah Continuous Improvement Spiral Model [8]. Model ini memungkinkan untuk 
pengembangan dan peningkatan sistem dapat dilakukan secara bekelanjutan. Metode dan perancangan sistem embedded cerdas menggunakan logika fuzzy dapat dilihat pada gambar 1 .

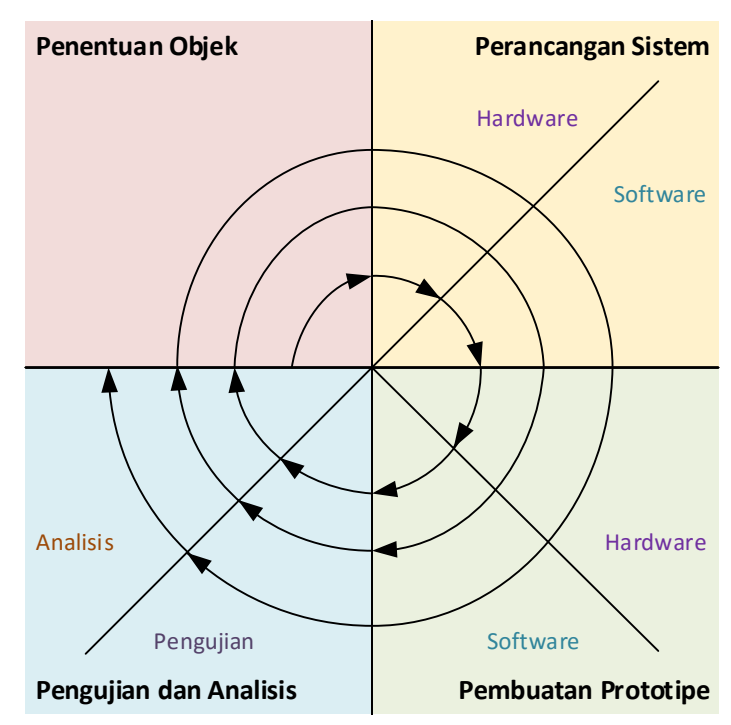

Gambar 1. Metode dan perancangan sistem

Dari Gambar 1 terlihat, tahapan penelitian terdiri dari: penentuan objek, perancangan sistem, pembuatan sistem dan prototipe (purwarupa), pengujian dan analisis. Objek dalam penelitian adalah efisiensi konsumsi energi peralatan elektronik rumah tangga yang sering digunakan pada daerah tropis meliputi: pendingin ruangan, lampu dan stopkontak. Sedangkan daerah non-tropis yang memiliki musim dingin, dapat dihubungkan dengan pemanas ruangan dan peralatan elektronik rumah tangga lainnya. Sensor yang digunakan dan objek peralatan elektronik dapat dilihat pada Gambar 2.

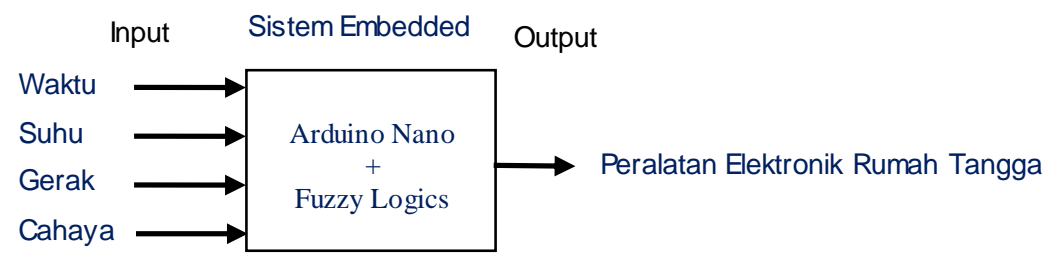

Gambar 2. Objek penelitian

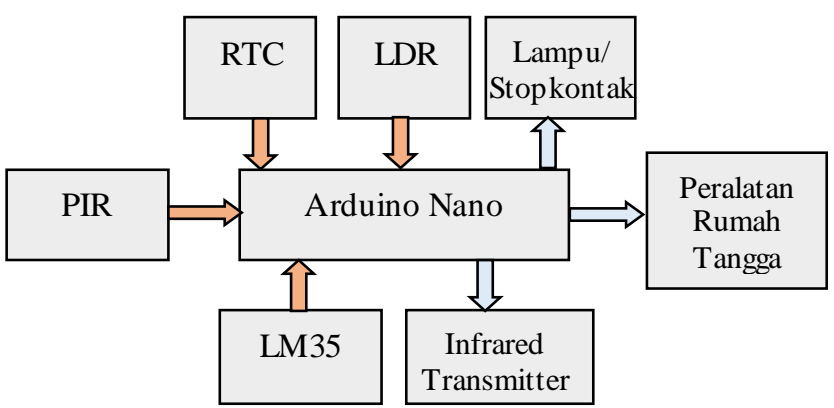

Gambar 3. Purwarupa perangkat keras

Pada Gambar 2 juga dijelaskan subjek dalam penelitian adalah sistem embedded menggunakan arduino nano yang telah di-embedded-kan dengan logika fuzzy didalamnya yang 
berfungsi untuk mengendalikan konsumsi energi berdasarkan input yang diperoleh dari sensor suhu, sensor cahaya, sensor gerak dan RTC.

Langkah berikutnya adalah pembuatan purwarupa sistem embedded menggunakan logika fuzzy. Pada tahap ini, pembuatan purwarupa dibagi menjadi dua bagian, yaitu perangkat keras dan perangkat lunak. Purwarupa perangkat keras dilakukan dengan mengintegrasikan sejumlah sensor sebagai masukan (input). Sensor-sensor yang diintegrasikan terdiri dari sensor suhu (LM35), sensor cahaya (LDR), sensor gerak (PIR), dan Real Time Clock (RTC). Sensor-sensor tersebut kemudian dihubungkan Arduino Nano.

Pada bagian luaran (output), Arduino Nano diintegrasikan dengan infrared transmitter dan beberapa peralatan listrik seperti lampu, stopkontak dan pendingin ruangan. Tujuannya adalah untuk menghidupkan dan mematikan peralatan listrik ketika ada pergerakan (manusia). Dengan demikian konsumsi energi dalam ruangan dapat dikontrol. Secara keseluruhan purwarupa perangkat keras dapat dilihat pada Gambar 3.

Untuk menjalankan perangkat keras tersebut, diperlukan suatu perangkat lunak yang menjalankan logika fuzzy. Pseudocode perangkat lunak tersebut dapat dilihat pada Gambar 4.

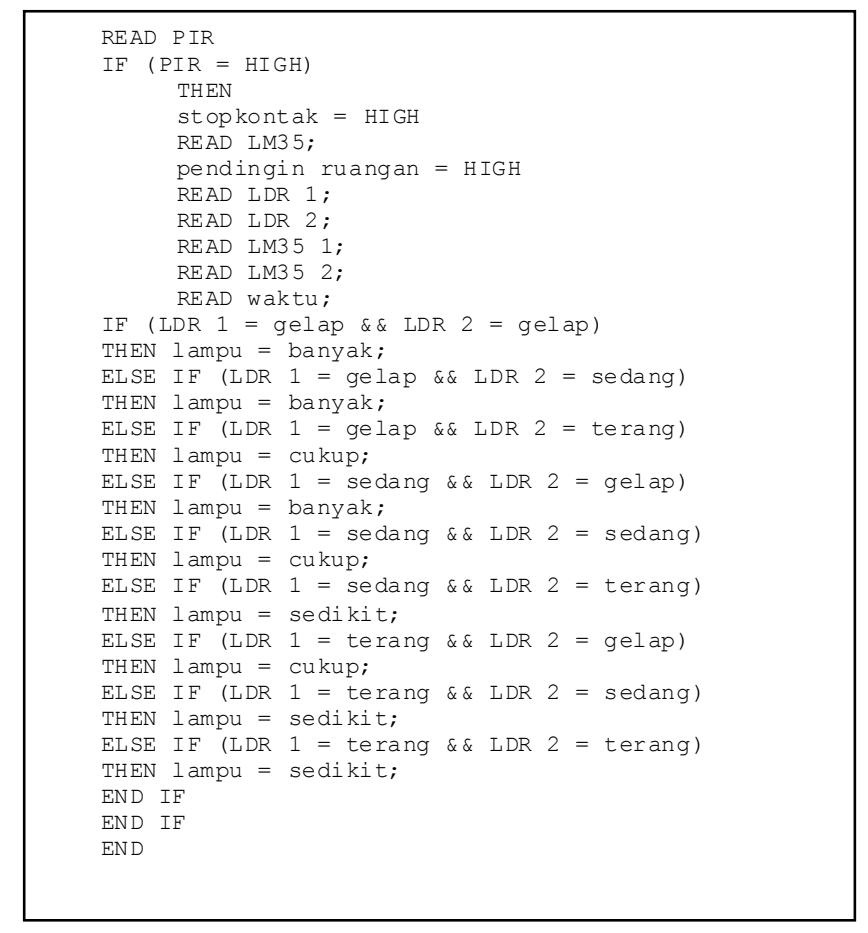

Gambar 4. Pseudocode perangkat lunak sistem embedded cerdas konsumsi energi

Pseudocode tersebut merupakan tahapan pemrosesan data yang diperoleh dari input dengan menggunakan logika fuzzy sehingga dapat mengeluarkan output yang diinginkan. Pada tahap awal (inisiasiasi), sistem menjalankan fungsi timer dan fungsi pembacaan sensor sebagaimana yang ditunjukkan pada Gambar 5 .

Fungsi Untuk Memulai Timer

time $=$ millis ();

Fungsi Untuk Membaca Sensor

$\mathrm{LDR} 1=$ a na $\log \operatorname{Re} a d(\operatorname{ldr} 1)$;

$\mathrm{LDR} 2=$ a na log Read ( $1 \mathrm{dr} 2)$;

suhu=a na logRead ( $\operatorname{lm} 351)$;

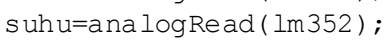

val = digital Read(pir);

Gambar 5. Fungsi timer dan fungsi pembaca sensor 
Tahap tersebut menghasilkan input yang berupa "crisp". Crisp merupakan input yang sebenarnya yang telah diukur oleh sensor dan dilewatkan untuk masuk ke sistem kontrol untuk pemrosesan lebih lanjut. Input tersebut kemudian diubah menjadi bentuk fuzzydengan melakukan fuzzifikasi. Adapun fungsi fuzzifikasi adalah sebagaimana yang ditunjukkan pada Gambar 6 .

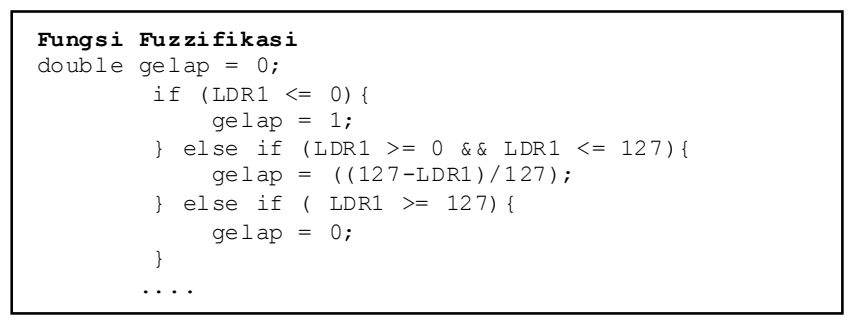

Gambar 6. Fungsi fuzzifikasi

Selanjutnya dilakukan inferensi fuzzy untuk memperoleh nilai fuzzy dan dapat menentukan aturan (rule) fuzzy dengan fungsi sebagaimana yang ditunjukkan Gambar 7.

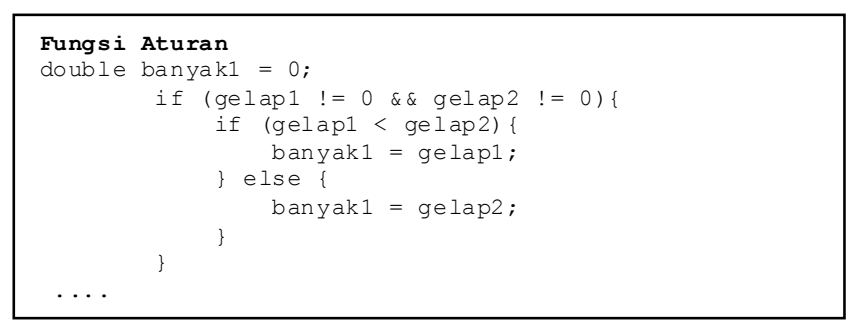

Gambar 7. Fungsi aturan (rule) fuzzy

Setelah didapat nilai fuzzy dan rule fuzzy maka dilakukan defuzzifikasi. Defuzzifikasi dilakukan dengan metode Mean of Maximum sebagai keputusan akhir dengan fungsi sebagaimana yang ditunjukkan Gambar 8.

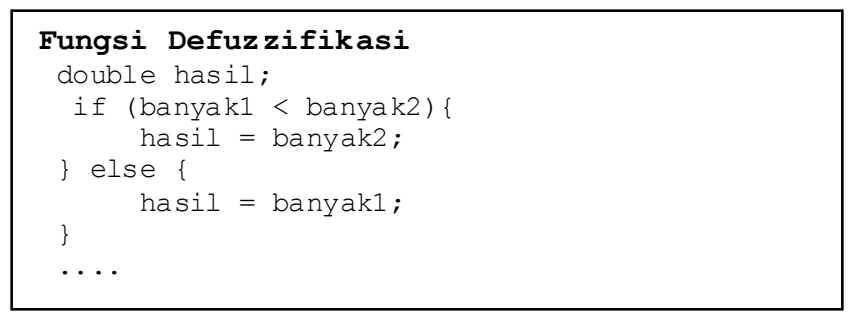

Gambar 8. Fungsi defuzzifikasi

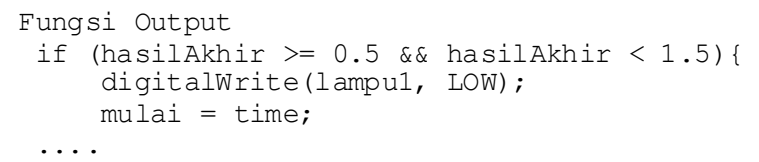

Gambar 9. Fungsi Output

Pada bagian akhir dari perancangan sistem embedded cerdas menggunakan logika fuzzy adalah proses untuk menghasilkan output. Output merupakan hasil akhir yang didapat setelah fungsi defuzzifikasi dijalankan. Fungsi output tersebut dapat dilihat pada Gambar 9. Purwarupa perangkat keras dan perangkat lunak kemudian diintegrasikan sehingga menjadi suatu sistem yang dapat mengendalikan konsumsi energi secara cerdas menggunakan logika fuzzy. 


\section{Hasil dan Pembahasan}

Untuk menganalis tingkat keberhasilan sistem yang telah dibuat, dilakukan sejumlah pengujian. Pengujian dilakukan selama 2 (dua) minggu dengan masing-masing 5 (lima) hari selama 9 (sembilan) jam. Dengan menggunakan peralatan listrik yang sama, pengujian dilakukan dengan sistem dan tanpa sistem (default). Hasil pengujian dapat dilihat pada Gambar 10.

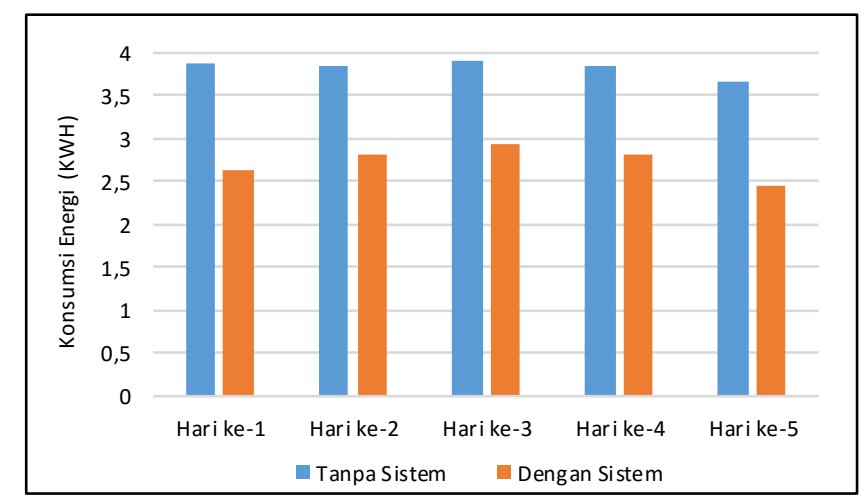

Gambar 10. Pengujian konsumsi energi

Pada minggu pertama pengujian dilakukan dengan menghidupkan semua lampu sebanyak 4 lampu, stopkontak dan pendingin ruangan sejak pukul $08.00 \mathrm{WIB}$ hingga pukul $17.00 \mathrm{WIB}$ sehingga diperoleh data seperti pada Gambar 10 yang kemudian dinamakan "Tanpa Sistem". Selanjutnya pada minggu kedua dilakukan pengujian dengan menggunakan sistem. Setelah instalasi prototype, pengujian dilakukan dengan peralatan listrik, kondisi, dan waktu yang sama. Dengan adanya sistem ini terjadi perubahan dimana lampu, stopkontak dan pendingin ruangan akan mati dan hidup jika ada pergerakan dan juga sesuai dengan pembacaan sensor suhu dan sensor cahaya. Setelah pengujian didapat data setiap harinya yaitu seperti pada Gambar 9 yang kemudian dinamakan "Dengan Sistem".

Untuk mengontrol pendingin ruangan dilakukan dengan komunikasi menggunakan infrared transmitter, untuk dapat melakukan komunikasi infrared, pertama kali harus mengetahui code yang dikirim dari remote pendingin ruangan ke pendingin ruangan sehingga pendingin ruangan dapat dihidupkan, dimatikan, diturunkan dan dinaikkan suhunya. Pada penelitian ini pendingin ruangan yang digunakan untuk pengujian adalah AC (Air Conditioner) Samsung 1/2 PK.

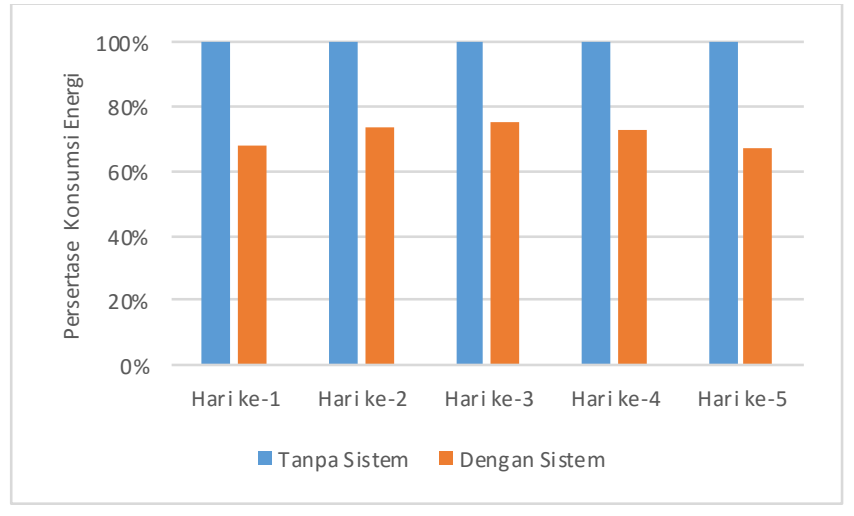

Gambar 11. Persentase efisiensi konsumsi energi listrik

Berdasarkan hasil yang didapatkan dari sejumlah pengujian pada saat penerapan sistem embedded cerdas menggunakan logika fuzzy terlihat bahwa konsumsi energi yang dihasilkan dengan adanya sistem ini lebih rendah dibandingkan nilai default (tanpa sistem). Hal tersebut dapat dilihat pada grafik perbandingan sebagaimana yang ditunjukkan pada Gambar 11. Dari gambar 10 dapat dilihat bahwa konsumsi energi rata-rata (default) tanpa sistem adalah 3.832 
Kwh/hari. Dengan penerapan sistem embedded cerdas menggunakan logika fuzzy, konsumsi energi rata-rata adalah $2.732 \mathrm{Kwh} / \mathrm{hari}$.

Secara keseluruhan konsumsi energi listrik dengan menggunakan sistem embedded menggunakan logika fuzzy selama waktu pengujian 5 (lima) hari dapat dilihat pada Gambar 12. Berdasarkan Tabel 2 terlihat bahwa penerapan sistem embedded cerdas menggunakan logika fuzzy mampu mengurangi konsumsi energi hingga $28.71 \%$.

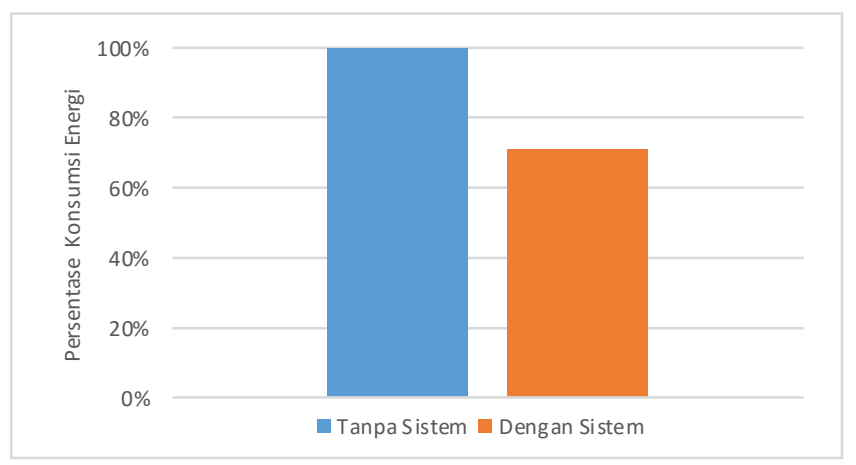

Gambar 12. Perbandingan konsumsi energi selama 5 (lima) hari pengujian

Pengendalian konsumsi energi setelah penerapan sistem logika fuzzy ini dapat menjadi lebih hemat dikarenakan lampu, stok kontak dan juga pendingin ruangan dapat dimatikan secara otomatis pada saat tidak digunakan. Dengan penggunaan sejumlah sensor, sistem ini dapat mendeteksi ada atau tidak adanya pergerakan pada suatu ruangan. Kelebihan sistem ini adalah bila tidak terdeteksi adanya pergerakan setelah jangka waktu tertentu (pada penelitian ini ditetapkan 10 menit), sistem akan secara otomatis memutuskan aliran listrik ke sejumlah perangkat listrik yang terintegrasi dengannya. Hasilnya adalah konsumsi energi peralatan listrik seperti lampu dan pendingin ruangan setiap harinya dapat digunakan secara efisien.

\section{Kesimpulan}

Sedikitnya pengguna listrik yang menyadari bahwa penggunaan energi selama ini kurang efektif dan efisien menyebabkan terjadinya pemborosan energi yang berpotensi memicu krisis lingkungan dan energi dunia. Dalam rangka penghematan dan efisiensi konsumsi energi listrik dirancang sebuah purwarupa sistem embedded cerdas menggunakan logika fuzzy yang ditanam pada Arduino nano dengan input sensor suhu, sensor cahaya, sensor gerak dan real time clock (RTC). Sistem tersebut digunakan untuk mengendalikan hidup matinya peralatan elektronik tersebut bila tidak digunakan. Hasil dari pengujian selama 5 hari (per hari 9 jam) dengan menggunakan sistem tertanam cerdas tersebut didapatkan efisiensi sebesar $28.71 \%$ dibandingkan dengan keadaan tidak menggunakan sistem tersebut.

\section{Referensi}

[1] U.S. Energy Information Administration. 1st edition International Energy Outlook 2017. Washington DC. U.S. EIA. 2017

[2] Mukherjee S, Nateghi R. Climate, Weather, Socio-Economic and Electricity Usage Data for the Residential and Commercial Sectors in FL, U.S. Elsevier Data in Brief. 2017; 13: 192195.

[3] Ghadi Y.Y, Rasul M.G, Khan M.M.K. Potential of Saving Energy Using Advanced Fuzzy Logic Controllers in Smart Buildings in Subtropical Climates in Australia," The Proceeding of 6th International Conference on Applied Energy - ICAE2014. Taipei, Taiwan. 2014; 61: 290293.

[4] Al - Jazaeri A.O, Samaranayake L, Longo S. Fuzzy Logic Control for Energy Saving in Autonomous Electric Vehicles, The Proceeding of 2014-IEEE International in Electric Vehicle Conference - IEVC-2014.Florence, Italy. $2014: 1-6$.

[5] Ghelli A, Hagras H, Aldabbagh G. A Fuzzy Logic-Based Retrofit System for Enabling Smart Energy-Efficient Electric Cookers. IEEE Transactions on Fuzzy Systems. 2015; 23(6): 19841997. 
[6] Shieh S.L, Chiou S.F, Cheng W.F, Lin B.L, Li J.Y, Lai Y.C. Application of Fuzzy Method to Solve the Use of Electrical Energy-Saving, IIAI 4th International Congress on Advanced Applied Informatics. Okayama, Japan. 2015: 433 - 436.

[7] George J.K, Bo Y. Fuzzy Sets and Fuzzy Logic: Theory and Application. Upper Saddle River, New Jersey: Prentice Hall. 1995.

[8] Boehm B.W, A Spiral Model of Software Development and Enhancement. IEEE Journal and Magazines. 1988; 21(5): 61-72. 